\title{
PERSEPSI MASYARAKAT TERHADAP KINERJA PEGAWAI KANTOR KELURAHAN RABADOMPU BARAT KOTA BIMA
}

\author{
Muhdin ${ }^{1)}$, Mistar $^{2}$ \\ Sekolah Tinggi Ilmu Ekonomi (STIE) Bima \\ muhdinstie15@gmail.com,mistar.stiebima@gmail.com
}

\begin{abstract}
Abstrak. Kelurahan Rabadompu Barat kota bima belum optimal dalam melaksanakan pelayanan admimistrasi kependudukan ditandai banyaknya problem yang dihadapi masyarakat bila berurusan dengan birokrat dalam pengurusan segala bentuk syarat-syarat yang menyangkut dengan kependudukan seperti: Surat Keterangan Domisili, Surat Keterangan Usaha, Surat Pindah, Surat Keterangan Tidak Mampu, dan lain sebagainya. penelitian ini bertujuan untuk mengetahui Persepsi Masyarakat Terhadap kinerja pegawai dalam Pelayanan Administrasi Kependudukan. Dari penelitian ini dilakukan untuk menjadi suatu bahan masukan bagi Pemerintah Kelurahan Rabadompu Barat kota bima. dengan menggunakan penelitian deskriptif atau studi eksplorasi, karena bertujuan menggambarkan keadaan atau fenomena yang terjadi di lapangan, dengan teknik pengumpulan data yang dilakukan menggunakan observasi, wawancara, dokumentasi, dan koesioner, analisis data dalam penelitian ini menggunakan teknik statistik deskriptif dengan teknik presentase. untuk mengidentifikasi jawaban-jawaban responden, Tabulasi hasil jawaban responden. Hasil penelitian Persepsi masyarakat terhadap kinerja pegawai yang ada di Kelurahan Rabadompu Barat kota bima mendapat penilaian yang cukup, kinerja lurah dan aparatnya dalam memberikan pelayanan kepada masyarakat dalam bentuk kepengurusan surat-surat pengantar, dan surat keterangan domisili, surat keterangan tidak mampu, mendapat tanggapan yang positif dari masyarakat, walaupun masih ada beberapa warga yang mengeluhkan kualitas layanan, terutama apabila lurah sedang tidak berada di kantor, karena surat-surat tersebut belum bisa ditandatangani.
\end{abstract}

Kata kunci: Administrasi, Kinerja, Masyarakat, Persepsi.

\section{PENDAHULUAN}

Kelurahan adalah pembagian wilayah administratif di Indonesia di bawah kecamatan, dalam konteks etonomi daerah di Indonesia. Kelurahan merupakan wilayah kerja lurah sebagai perangkat daerah kabupaten atau kota. Sesuai dengan nomor 73 tahun 2005, kelurahan adalah merupakan wilayah kerja lurah sebagai perangkat daerah kabupaten/kota dalam wilayah kecamatan. Pembentukan kelurahan harus sekurang kuragnya memenuhi syarat:

1. Jumlah penduduk

2. Luas wilayah

3. Bagian wilayah kerja

4. Sarana dan prasarana pemerintahan
Pemerintah kelurahan adalah memiliki kemandirian dan akuntabilitas publik yang cukup memadai, dalam interaksinya yang bersifat langsung dengan masyarakat diwilayah kerjanya.Sebagai unit pelaksana pemerintahan yang terendah dibawah kecamatan, jenis-jenis pelayanan yang dapat dikoordinasikan penyelenggaraanya oleh lurah adalah beragam dengan kriteria yang mencakup pelayanan kebutuhan dasar masyarakat; seperti pelayanan kelengkapan data untuk pembuatan KTP, pencatatan akta tanah, pelayanan keterangan untuk kesehatan, penyuluhan masyarakat, tata pembagian air untuk pertanian (irigasi) dan sebagainya.

Dalam menyelenggarakan pemerintah kelurahan, lurah dibantu perangkat kelurahan. Perangkat kelurahan terdiri dari sekertaris kelurahan dan seksi- seksi serta 
jabatan fungsional. Dalam melaksanakan tugasnya, perangkat kelurahan bertanggung jawab kepada lurah. Perangkat kelurahan, diisi dari pegawai sipil yang diangkat oleh sekertaris daerah kabupaten/kota usul camat. Ketentuan lebih lanjut mengenai struktur organisasi dan kata kerja kelurahan diatur dengan praturan daerah kabupaten/kota.

Dikelurahan dapat dibentuk lembaga kemasyarakatan. Pembentukan lembaga kemasyarakatan dilakukan atas prakasa masyarakat melalui musyawarah dan mufakat. Lembaga kemasyarakatan mempunyai tugas membantu lurah dalam pelaksanaan urusan pemerintah, pembangunan, sosial kemasyarakatan dan pemberdayaan masyarakat. Dari pemahaman terhadap ruang lingkupkelurahan, maka elemen utama dari suatu keluraha terdiri dari:

1. Kesatuan wilayah administrasi dengan segenap konsep potensi sumber daya yang dimiliki.

2. Penduduk sebagai warga masyarakat, dan kelempok-kelompok masyarakat,

3. Pemerintah desa dan kelurahan,

4. Aktivitas sosial ekonomi masyarakat dalam memenuhi kebutuhan mereka sendiri.

Seperangkat aturan, tradisi dan kebiasaan yang dijunjung bersama untuk mencapai tujuan bersama. Elemen utama tersebut selanjutnya sebagai fokus dan fokus pelaksanaan kebijakan dan program pembangunan masyarakat. Pengembangan kebijakan dan program pembangunan masyarakat desa tersebut dilakukan oleh suatu organisasi yang berkedudukan di pusat provinsi dan kabupaten/kota serta kecamatan.

Seiring diberlakukannya UU No. 25 tahun 2009 tentang pelayanan publik dan UU No. 14 Tahun 2008 tentang keterbukaan informasi publik yang telah memberikan jaminan kepada seluruh warga
Negara untuk mendapatkan pelayanan yang baik. Pelayanan publik yang baik diukur dari pencapaian kepuasan yang dirasakan oleh semua pihak baik yang dilayani maupun yang melayani. Pelayanan kelurahan tergolong dalam jenis pelayanan publik karena adanya kepentingan umum yang dilayani oleh kelurahan.

Dijelaskan dalam Undang-Undang Nomor 32 Tahun 2004 tentang pemerintahan daerah, pasal 127 ayat 1 bahwa kelurahan dibentuk dalam wilayah kecamatan dengan peraturan Daerah berpedoman pada peraturan pemerintah. Kemudian, dalam ayat 2 dijelaskan bahwa kelurahan sebagaimana dimaksud pada ayat 1 dipimpin oleh lurah yang dalam pelaksanaan tugasnya memperoleh pelimpahan dari Bupati/Walikota.

Oleh karena itu, dalam pencapaian tujuan masing-masing instansi ini, tidak terlepas dari peranan pemimpin dalam mengarahkan, membimbing, dan memotivasi pegawainya. Baik buruknya kinerja pegawai di Kelurahan Rabadompu Barat tidak terlepas dari gaya kepemimpinan yang diterapkannya. Kinerja pegawai berpengaruh terhadap pemberian layanan pada masyarakat.Tidak selamanya kinerja para pegawai dalam kondisi yang kondusif, terkadang kinerja yang mereka hasilkan menurun seperti yang Nampak pada permasalahan yang telah dijelaskan diatas.

Keadaan ini akan berdampak pada ketidak puasan layanan pada masyarakat. Hal inilah yang memicu timbulnya permasalahan antara lain, complain dari masyarakat, kekecewaan masyarakat, pemberian layanan pada masyarakat yang kurang maksimal, dan lain-lain. Kelurahan Rabadompu barat ditandai banyaknya problem yang dihadapi masyarakat bila berurusan dengan birokrat dalam pengurusan segala bentuk syarat-syarat yang menyangkut dengan kependudukan seperti: Surat Keterangan Domisili, Surat 
Keterangan Usaha, Surat Pindah, Surat Keterangan Tidak Mampu, dan lain sebagainya serta tidak adanya fasilitas kotak pengaduan atau kritikan di kantor kelurahan,menjadi rahasia umum dimata masyarakat terhadap rendahnya kualitas pelayanan publik dikarenakan pegawai yang sangat sedikit, kualitas kantor yang masih dibawah standar dan lain sebagainya.

Berdasarkan observasi awal yang dilakukan mengenai kinerja pegawai dalam pelayanan pemerintah Kelurahan Rabadompu barat, ditemukan bahwa banyaknya keluhan yang disampaikan oleh warga, tentang pelayanan yang masih belum sesuai harapan masyarakat, dimana lurah mempunyai kinerja yang rendah, terutama dalam bidang pelayanan administrasi kependudukan. Pengurusan surat-surat yang dibutuhkan oleh warga seringkali tertunda akibat ketidakhadiran lurah sebagai pejabat yang berkompeten menandatangani surat-surat tersebut.

\section{KAJIAN TEORI}

\section{Persepsi}

Persepsi menurut Marliani (2010) dalam bahasa inggris persepsi adalah perception,yaitu cara pandang terhadap sesuatu atau mengutarakan pemahaman hasil olahan daya pikir,artinya persepsi berkaitan dengan faktor-faktor eksternal yang direspon melalui panca indera,daya ingat,daya jiwa.

Persepsi merupakan cara pandang seseorang yang berbeda secara objek yang dilihat dan dirasakan berdasarkan pengamatan, pemahaman dan pengalaman yang kemudian diwujudkan dalam konsep persepsi yang meliputi indikator pemahaman, tanggapan dan harapan, gladyensi (2019).

Persepsi akan timbul setelah seseorang atau sekelompok manusia terlebih dahulu merasakan kehadiran suatu objek dan setelah dirasakan akan menginterprestasikan objek yang dirasakan tersebut, seperti pendapat Young (dalam Walgito, 2010).

\section{Kinerja}

Kinerja menurut Prabumangkunegara (2009) mengemukakan bahwa kinerja adalah hasil kerja secara kualitas dan kuantitas yang dicapai oleh seorang pegawai dalam melaksanakan tugasnya sesuai dengan tanggung jawab yang diberikan kepadanya.

Menurut Moeheriono (2012), indikator untuk mengukur kinerja pegawai yaitu: a. Kualitas Kualitas kerja diukur dari persepsi karyawan terhadap kualitas pekerjaan yang dihasilkan serta kesempurnaan tugas terhadap keterampilan dan kemampuan pegawai.b. Kuantitas Kuantitas merupakan jumlah yang dihasilkan dinyatakan dalam istilah seperti jumlah unit, jumlah siklus aktivitas yang diselesaikan. c. Ketepatan waktu Ketepatan waktu merupakan tingkat aktivitas diselesaikan pada awal waktu yang dinyatakan, dilihat dari sudut koordinasi.

\section{Indikator Kinerja pegawai}

Dalam jurnal sari, (2016) mengemukakan bahwa indicator kinerja, yaitu:

1. Kualitas kerja adalah seberapa baik seorang karyawan mengerjakan apa yang seharusnya dikerjakan.

2. Kuantitas kerja adalah seberapa lama seorang pegawai bekerja dalam satu harinya.Kuantitas kerja ini dapat dilihat dari kecepatan kerja setiap pegawai itu masing-masing.

Pelaksanaan Tugas adalah seberapa jauh karyawan mampu melakukan pekerjaannya dengan akurat atau tidak ada kesalahan. 


\section{METODE PENELITIAN}

\section{Jenis penelitian}

Menurut Punaji (2010) penelitian deskriptif adalah penelitian yang tujuannya untuk menjelaskan atau mendeskripsikan suatu peristiwa, keadaan, objek apakah orang, atau segala sesuatu yang terkait dengan variabel-variebel yang bisa dijelaskan baik menggunakan angka-angka maupun kata-kata.

\section{Populasi, sampel, dan sampling penelitian}

Populasi yang digunakan adalah masyarakat sebanyak 4.794 dengan sampel menurut Sugiyono (2010 : 91) bahwa sampel adalah bagian dari jumlah dan karakteristik yang dimiliki oleh populasi tersebut. Adapun sampel dalam penelitian ini adalah warga rabadompu barat sebanyak 100 orang.

Adapun sampling dalam penelitian ini adalah simple random sampling Menurut Kerlinger (2006:188), simple random sampling adalah metode penarikan dari sebuah populasi atau semesta dengan cara tertentu sehingga setiap anggota populasi atau semesta tadi memiliki peluang yang sama untuk terpilih atau terambil.

\section{Instrument penelitian dan tehnik pengumpulan data}

a. Instrumen penelitian

adalah suatu alat yang digunakan untuk mengukur fenomena alam maupun sosial yang diamati secara spesifik, semua fenomena ini disebut variabel penelitian (Sugiyono, 2010).Instrumen penelitian yang digunakan dalam penelitian ini adalah kuesioner dengan indikator persepsi masyarakat terhadap kinerja pegawai. b. Teknik pengumpulan data

Untuk memperoleh data-data dalam penelitian ini penulis mempergunakan teknik pengumpulan data sebagai berikut :

Pengamatan/Observasi yaitu dengan mengadakan observasi secara langsung kepada objek yang diteliti untuk memperoleh data yang dibutuhkan atau yang ada kaitannya dengan permasalahan yang diangkat. Menurut sugiyono(2010) mengatakan bahwa observasi disebut dengan pengamatan, yakni mengamati secara langsung obyek yang diteliti.

Interview (Wawancara), yaitu dengan melakukan wawancara atau interview secara langsung terhadap sejumlah staf, pegawai dan masyarakat yang telah ditentukan oleh peneliti tersebut.

Dokumentasi yaitu sebuah proses pengumpulan data yang sistematis hingga data tersebut dikelola dan menghasilkan dokumentasi Lokasih penelitian

Kuesioner adalah suatu teknik pengumpulan informasi yang memungkinkan analis mempelajari sikapsikap, keyakinan, perilaku, dan karakteristik beberapa orang utama di dalam organisasi yang bisa terpengaruh oleh sistem yang diajukan atau oleh sistem yang sudah ada.

Penelitian ini dilakukan pada kantor Kelurahan Rabadompu Barat Kota Bima. Dengan kuisioner ini responden mudah memberikan jawaban karena alternative jawaban sudah disediakan dan membutuhkan waktu yang singkat dalam menjawabnya.

\section{HASIL DAN PEMBAHASAN}

Penelitian ini berdasarkan data Kuesioner yang dibagikan pada masyarakat kelurahan Rabadompu Barat Kec. Raba Kota Bima-NTB. Untuk menjawab hipotesis Penelitian. Adapun tahapan- 
tahapan pengujian Hipotesis sebagai berikut:

\section{Uji Validitas}

Uji validitas dilakukan untuk mengetahui tingkat kevalitan dan instrument atau (kosioner) yang digunakan dalam pengumpulan data. Yang diperoleh dengan cara mengkorelisasi setiap skor variable jawaban dengan total skor masing masing variable, kemudian hasil korelasi dibandingakan dengan nilai kritis pada taraf signifikan 0,05 dan 0,01. Tinggi rendahnya validitas instrument akan menunjukan sejauh mana data yang terkumpul tidak menyimpang dari gambaran tentang variabel yang dimaksud.

Berdasarkan output di atas diketahui angka $\mathrm{r}_{\text {hitung }}$ untuk Peryataanl sebesar 0,574 Pernyataan2 sebesar 0,589 Pernyataan3 sebesar 0,488 Pernyataan4 sebesar 0,901 Pernyataan5 sebesar 0,547 Pernyataan6 sebesar 0,546 Pernyataan7 sebesar 1 Pernyataan8 sebesar 0,527. Hasil tersebut menunjukan bahwa pertanyaan no.1 sampai dengan Pernyataan no.8 adalah valid karena nilai $\mathrm{r}_{\text {hitung }}$ lebih besar dari 0,1956.

\section{Uji Reliabilitas}

Uji Reliabilitas digunakan untuk mengetahui eksistensi alat ukur, apakah alat ukur yang digunakan dapat diandalkan. Seperti yang diketahui bahwa dalam penelitian ini menggunakan instrument skala likert. Maka digunakan metode alpha cronbach's.

Berdasarkan hasil pengujian Reliabilitas di atas, diketahui Cronbach Alpha adalah sebesar 0,915. Jadi angka tersebut $(0,915)$ lebih besar dari nilai minimal cronbach alpha 0,6 . Oleh karena itu dapat disimpulkan bahwa instrument penelitian yang digunakan untuk mengukur variabel kinerja pegawai dapat dikatakan reliable atau handal.

\section{Uji T One Sample}

One sample $\mathrm{t}$ test merupakan teknik analisis untuk membandingkan satu variabel bebas. Teknik ini digunakan untuk menguji apakah nilai tertentu berbeda secara signifikan atau tidak dengan rata-rata sebuah sampel. Tabel one sample statistics diatas menunjukan nilai statistic deskriptif, yaitu $\mathrm{N}=100$ artinya jumlah sample yang dipakai adalah 100 orang .mean $=26,65$ artinya nilai rata- rata hitung adalah 26,65. Std. devition atau simpangan baku adalah sebesar 4,480 dan std. eror mean adalah sebesar 448.

Berdasarkan tabel one-sample test di atas diketahui nilai sig. (2-tailed) sebesar $0,000<0,05$ dan $t_{\text {hitung }}$ sebesar 59,490 > $\mathrm{t}_{\text {tabel }}$ 1,984 maka dapat disimpulkan bahwa hipotesis yang mengatakan "Persepsi masyarakat Terhadap kinerja pegawai pada kantor kelurahan lebih besar atau sama dengan 50\%" dapat diterima dikarenaka Nilai thitung lebih dari tabel.

\section{KESIMPULAN DAN SARAN}

\section{Kesimpulan}

Berdasarkan hasil analisa data yang dilakukan diatas maka dapat ditarik kesimpulan dalam penelitian ini sebagai berikut:

1. Dari perhitungan nilai $t_{\text {hitung }}$ yang dilakukan maka didapat nilai adalah sebesar 59,490 maka ditentukan derajat kebebasan $\quad(\mathrm{dk})=(\mathrm{n}-1=100-1=99)$, dimana taraf kesalahan yang ditentukan adalah 5\% (0,05) sehingga nilai $t_{\text {tabel }}$ yang diperoleh adalah sebesar 1,984 .

2. Nilai thitung dibandingkan dengan nilai $t_{\text {tabel }}$ maka diperoleh thitung lebih besar dari pada $t_{\text {tabel }}\left(59,490>t_{\text {tabel }} 1,984\right)$ jadi 
berdasarkan hipotesihnya yang menyatakan "persepsi masyarakat terhadap kinerja pegawai pada kantor kelurahan rabadompu barat kota bima lebih besar 50\%" diterima.
Sugiyono. 2010. Metode Penelitian Administratif. Bandung: Alfabeta.

Walgito, Bimo. 2010. Psikologi Sosial. Yogyakarta: Andi Offset.

\section{Saran}

Berdasarkan pembahasan hasil analisa data dan kesimpulan-kesimpulan diatas maka peneliti dapat memberikan saran kepada seluruh pegawai khususnya kepala kantor Kelurahan Rabadompu Barat Kota Bima agar terus mempertahankan dan bila perlu dipertingkatkan lagi tentang kinerja pegawai dalam melayani masyarakat.

\section{DAFTAR PUSTAKA}

Anwar, Prabu Mangkunegara. 2009. Evaluasi Kinerja Sumber Daya Manusia. Bandung: Penerbit Refika Aditama.

Kerlinger. 2006. Asas-Asas Penelitian Behaviour. Edisi 3, Cetakan 7. Yogyakarta: Gadjah Mada University Press.

Marliani. 2010. Kebijakan Publik. Jakarta: Toto.

Matsumoto, David. 2008. Psikologi Pengantar Lintas Budaya. Yogyakarta: Pustaka Pelajar.

Miftah, thoha. 2007. Perilaku Organisasi (konsep dasar dan aplikasi). Jakarta: PT Raja Grafindo Persada.

Moeheriono. 2012. Indikator Kinerja Utama (IKU): Perencanaan, Aplikasi dan Pengembangan. Jakarta: PT Grafindo Persada Sari.

Setyosari, Punaji. 2010. Metode Penelitian dan Pengembangan. Jakarta: Kencana. 